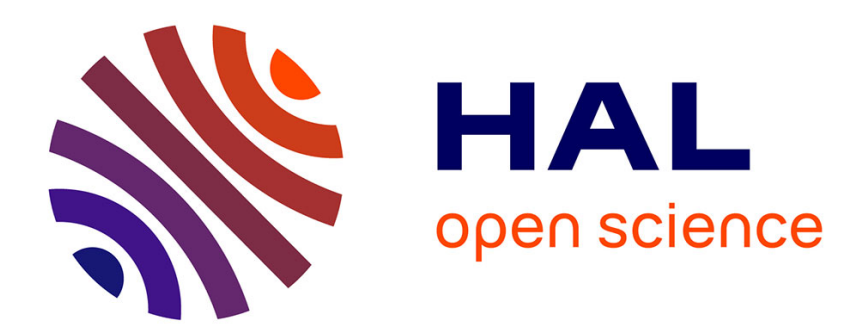

\title{
A little bit of ammonium may be good for your brain
} Païkan Marcaggi, Jonathan A. Coles

\section{To cite this version:}

Païkan Marcaggi, Jonathan A. Coles. A little bit of ammonium may be good for your brain. Physiology News, 2008, 73, pp.15-17. hal-03501565

\section{HAL Id: hal-03501565 \\ https://hal.science/hal-03501565}

Submitted on 7 Jan 2022

HAL is a multi-disciplinary open access archive for the deposit and dissemination of scientific research documents, whether they are published or not. The documents may come from teaching and research institutions in France or abroad, or from public or private research centers.
L'archive ouverte pluridisciplinaire HAL, est destinée au dépôt et à la diffusion de documents scientifiques de niveau recherche, publiés ou non, émanant des établissements d'enseignement et de recherche français ou étrangers, des laboratoires publics ou privés. 

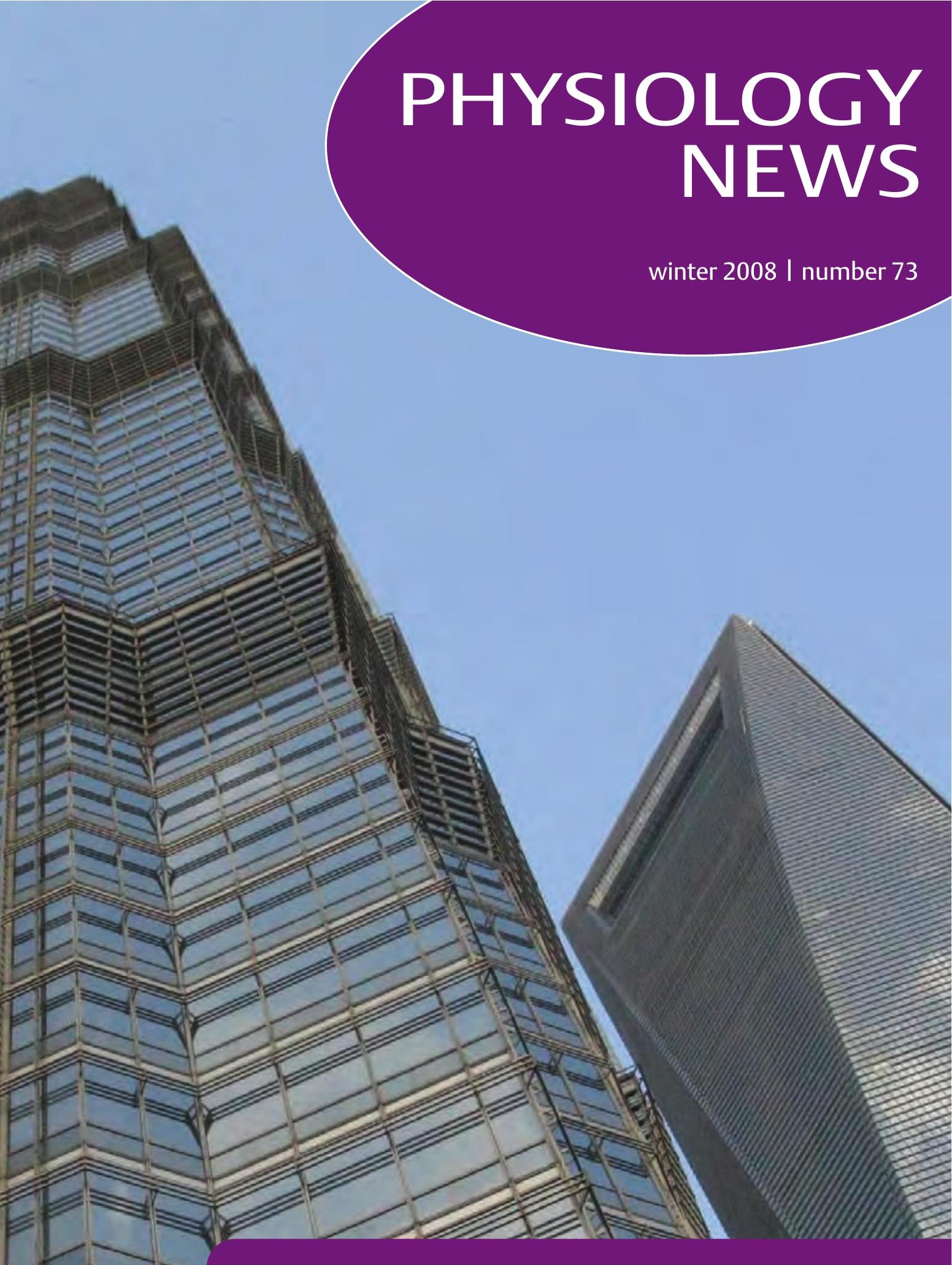

The HoD delusion

A Christmas party trick with an intriguing physiology A new organisation for the biosciences Ion channel techniques in Shanghai

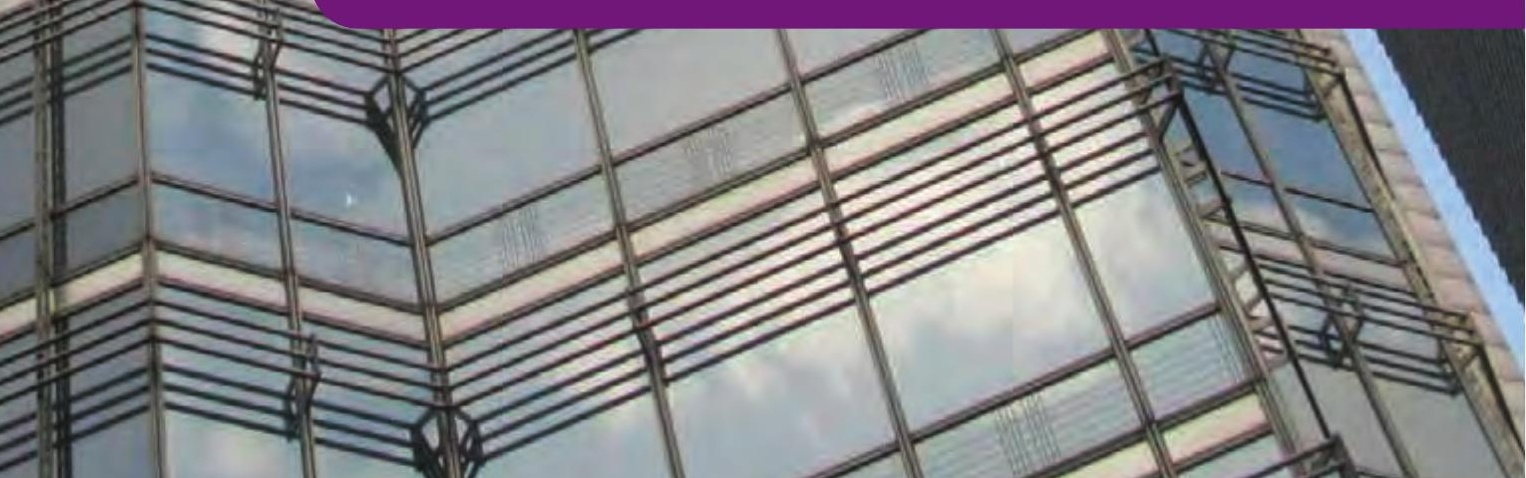




\section{A little bit of ammonium may be good for your brain}

Although specific ammonium-transporting proteins are well known in bacteria and plants, only recently has molecular and functional evidence begun to accumulate for ammonium transporters in animals. We describe how an ammonium transporter on the glial cells of bee retina plays an essential role in energy metabolism, and suggest an update of an old idea of a neuron-astrocyte flux of ammonium at synapses in mammalian brain

\section{Ammonium transporters are widespread}

It is convenient to use the word 'ammonium' to include $\mathrm{NH}_{4}{ }^{+}$(the 'ammonium' of chemists), $\mathrm{NH}_{3}$ ('ammonia') and the mixture of the two that spontaneously forms in water. At physiological pHs the equilibrium mixture contains about $98 \% \mathrm{NH}_{4}{ }^{+}$and $2 \% \mathrm{NH}_{3}$ (see Marcaggi \& Coles, 2001). $\mathrm{NH}_{3}$ can diffuse through lipid membranes (although not nearly as well as oxygen does). As shown by measuring intracellular $\mathrm{pH}$, if you add $\mathrm{NH}_{4} \mathrm{Cl}$ outside a cell, $\mathrm{NH}_{3}$ entering the cell tends to alkalinize the cytoplasm because about $98 \%$ of the $\mathrm{NH}_{3}$ combines with $\mathrm{H}^{+}$(Fig. 1). In practice, some ammonium goes in as $\mathrm{NH}_{4}{ }^{+}$, not $\mathrm{NH}_{3}$. A small fraction (about 2\%) of this entering $\mathrm{NH}_{4}{ }^{+}$dissociates to form $\mathrm{NH}_{3}$ and some $\mathrm{H}^{+}$ions: the entering flux of $\mathrm{NH}_{4}{ }^{+}$would have to be more than about 50 times that of $\mathrm{NH}_{3}$ to produce a net acid shift. In most cells there is an initial alkalinisation caused by $\mathrm{NH}_{3}$ entry, then $\mathrm{NH}_{4}{ }^{+}$entry produces a slow secondary acidification, but in some cells there is a primary acid shift, indicating that they take up overwhelmingly the $\mathrm{NH}_{4}{ }^{+}$form ${ }^{1}$. The $\mathrm{NH}_{4}{ }^{+}$ion is about the same size as a $\mathrm{K}^{+}$ion and the conservative suggestion was that $\mathrm{NH}_{4}{ }^{+}$was just leaking in via $\mathrm{K}^{+}$ channels or transporters. However, proteins of the Rh family (notorious for the immune reactions of $\mathrm{Rh}(-)$ foetuses to the blood of a $\mathrm{Rh}(+)$ mother) which are expressed not only in erythrocytes but also in kidney, liver, testes and parts of the brain, have homology with the Amt family of ammonium transporters,

\footnotetext{
${ }^{1}$ It is easy to get the textbook alkaline response: you simply use a damaged cell with an unphysiologically low intracellular $\mathrm{pH}$.
}

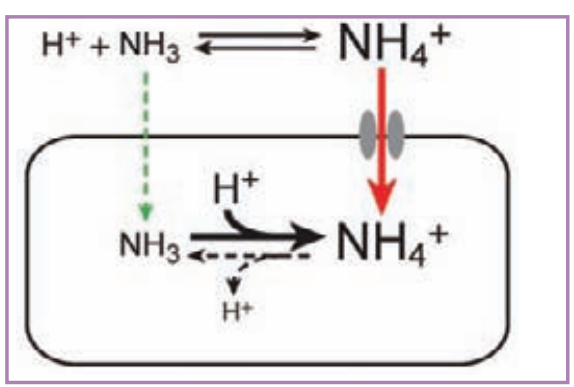

Figure 1 (left). Ammonium entry into a cell. Entry of $\mathrm{NH}_{3}$ produces a large alkalinisation. Entry of a similar amount of $\mathrm{NH}_{4}{ }^{+}$produces a much smaller acidification.

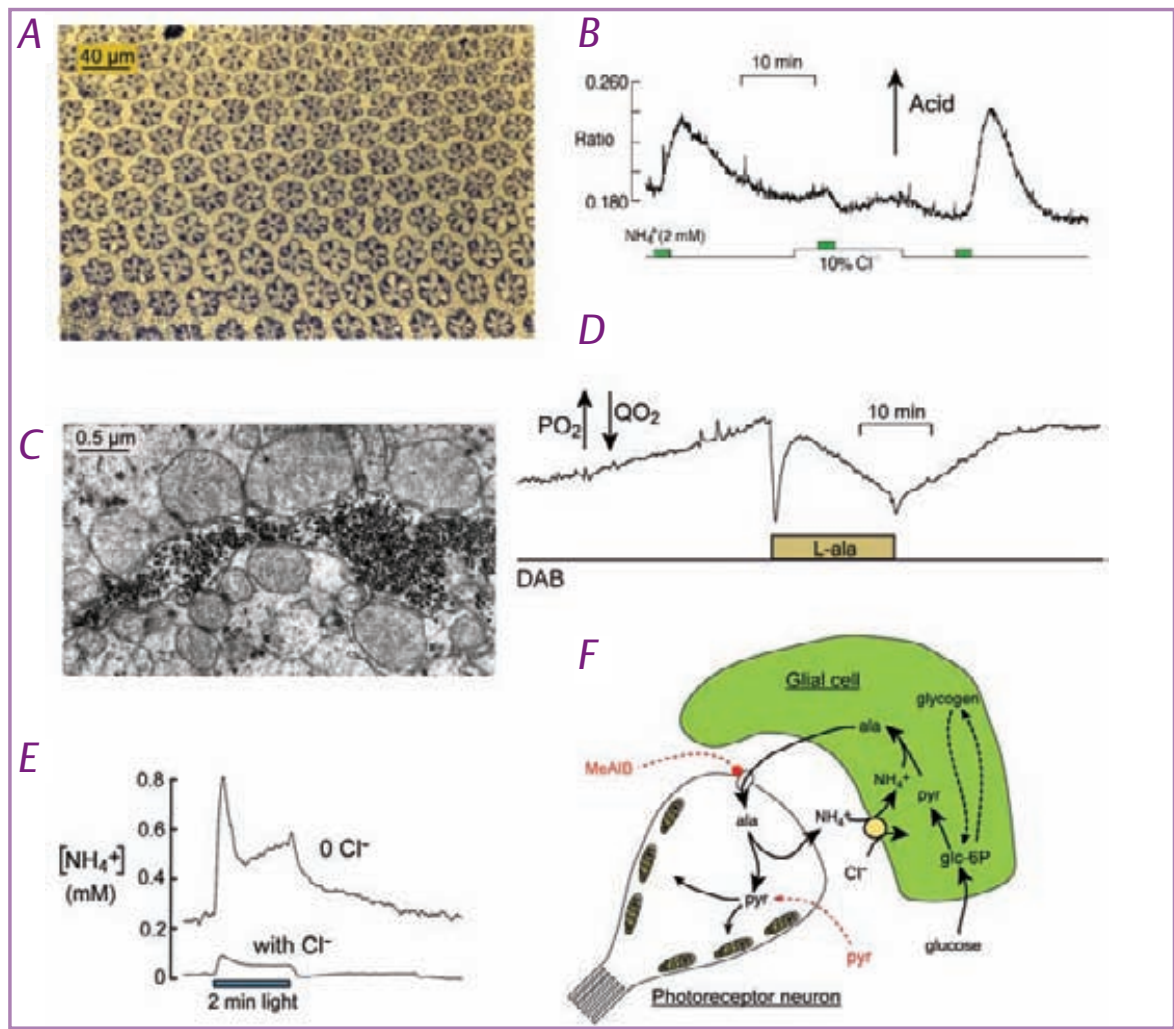

Figure 2. A, A section through a drone retina. Each rosette is composed of six, large, identical photoreceptors, $450 \mu \mathrm{m}$ long, which receive light passing through one corneal facette. Each rosette is surrounded by about $35 \mathrm{glial}$ cells. There are no blood vessels or chemical synapses (micrograph by PM Orkand). $B$, Application of ammonium (green rectangles) acidifies an isolated bundle of glial cells, and this acidification is blocked when the concentration of $\mathrm{Cl}^{-}$is reduced. This suggests $\mathrm{NH}_{4}{ }^{+}-$ $\mathrm{Cl}^{-}$cotransport (from Marcaggi et al [1999]. Eur] Neurosci 11, 167-177). C, An electron micrograph showing part of two glial cells, packed with glycogen granules, and part of a photoreceptor containing many mitochondria (from A Perrelet). $D, \mathrm{PO}_{2}$ in a bee retinal slice measured with an $\mathrm{O}_{2}$ microelectrode. DAB, present throughout this recording, reduces supply of fuel from glial glycogen so consumption of $\mathrm{O}_{2}\left(\mathrm{QO}_{2}\right)$ falls and $\mathrm{PO}_{2}$ rises. Application of alanine restores consumption. $E$, $\left[\mathrm{NH}_{4}^{+}\right]$ in extracellular clefts. In normal Ringer solution, $\left[\mathrm{NH}_{4}{ }^{+}\right]$was hardly detected in the dark or during light stimulation of the photoreceptors ("with $\left.\mathrm{Cl}^{-"}\right)$. When glial uptake was reduced by removing $\mathrm{Cl}^{-}\left(" 0 \mathrm{Cl}^{-"}\right)$ a much greater $\left[\mathrm{NH}_{4}^{+}\right]$signal was measured. $F$, Scheme of metabolic exchange in drone retina. Methylaminoisobutyrate is thought to reduce alanine uptake (red dot), and pyruvate bypasses the alanine flux (red arrow). (Figs. D, E, F adapted from Coles et al. 2008) . 


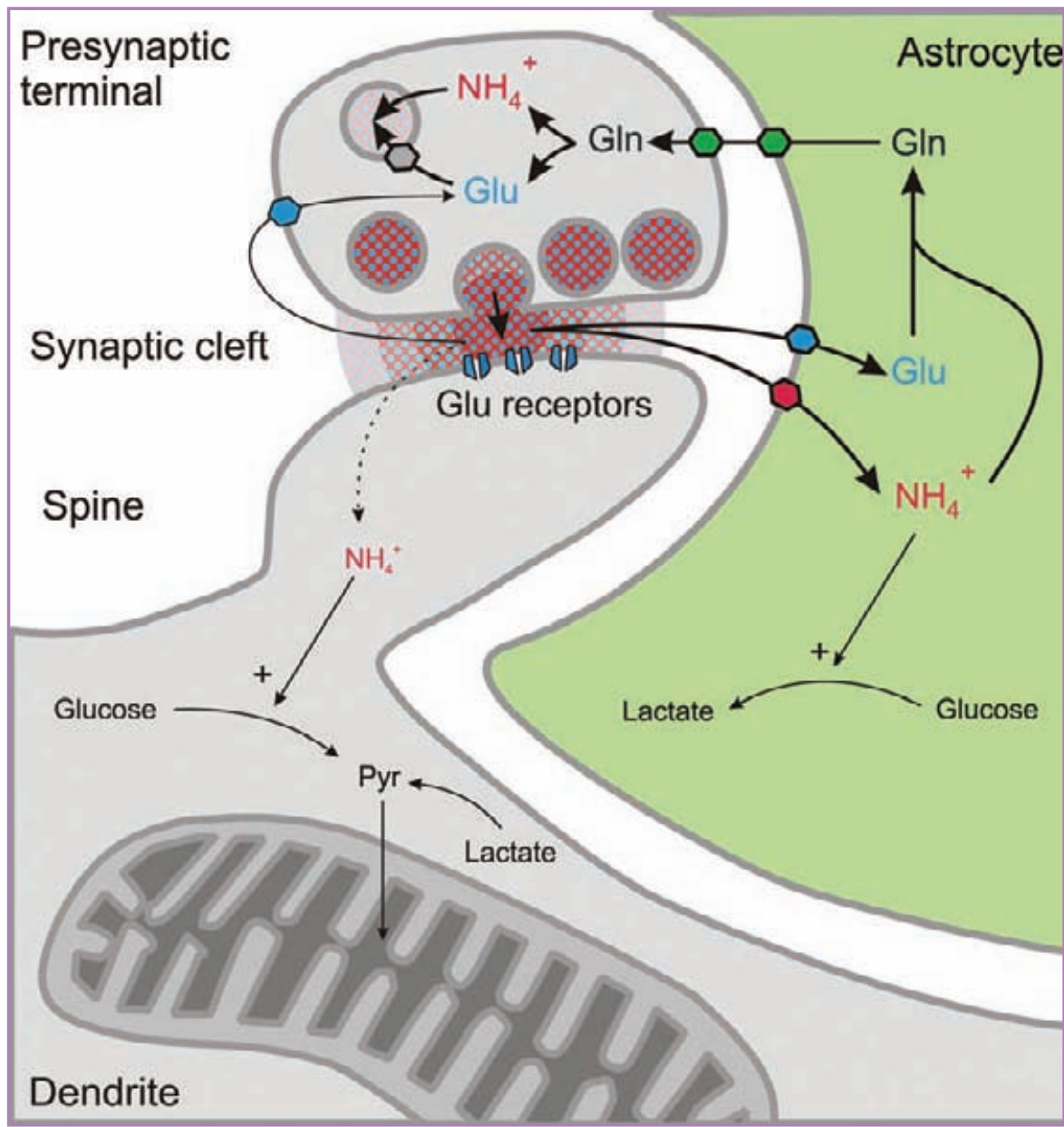

Figure 3. The glutamate/glutamine shuttle at a vertebrate glutamatergic synapse showing the ammonium flux suggested by Benjamin \& Quastel (1975), and the accumulation of ammonium together with glutamate in the synaptic vesicles suggested by Marcaggi (2006).

found in apparently all organisms up to and including invertebrates (Huang \& Peng, 2005).

There is general agreement that Amt and $\mathrm{Rh}$ proteins have an external binding site for $\mathrm{NH}_{4}^{+}$, but lively debate about what happens next. One possibility is that a proton is stripped off $\mathrm{NH}_{4}{ }^{+}$to leave $\mathrm{NH}_{3}$ which passes through a channel, but there are also reports of electrogenic transport, i.e. transport of $\mathrm{NH}_{4}{ }^{+}$or cotransport of $\mathrm{NH}_{3}$ and $\mathrm{H}^{+}$(Javelle et al. 2008). Surprisingly, although Amt/Rh proteins are so widespread, the first ammonium transport selective for $\mathrm{NH}_{4}{ }^{+}$over $\mathrm{K}^{+}$to be demonstrated in an animal cell appears to be by another, molecularly different variety of ammonium transporter found in the honeybee retina.

2 1,4-Dideoxy-1,4-imino-D-arabinitol.
A $\mathrm{NH}_{4}{ }^{+}$-selective cation-Cl- cotransporter on glial cells of the bee retina

The drone (male) honeybee has a large eye, which is useful for spotting high-flying queens, and whose retina is composed almost exclusively of photoreceptor neurons and a homogeneous population of glial cells, arranged with impressive regularity (Fig. 2A). When the intracellular $\mathrm{pH}$ of retinal glial cells is measured with a $\mathrm{pH}$-sensitive fluorescent dye, application of ammonium is found to produce a robust intracellular acidification that is abolished in the absence of $\mathrm{Cl}^{-}$(Fig. $2 B$ ). This suggests co-transport with $\mathrm{Cl}$. The transporter is selective for $\mathrm{NH}_{4}{ }^{+}$over $\mathrm{K}^{+}$(Marcaggi \& Coles, 2000 ), but it shares with a wide range of $\mathrm{K}^{+}-\mathrm{Cl}^{-}$cotransporters the presence of inhibitory binding sites for bumetanide and piretanide.
These results suggest a $\mathrm{NH}_{4}{ }^{+}-\mathrm{Cl}$ cotransporter which may be molecularly related to $\mathrm{K}^{+}-\mathrm{Cl}^{-}$ cotransporters, but which is different from ammonium transporters of the Amt/Rh superfamily. The bee genome includes three Amt/Rh genes, thus making a minimum possible total of four ammonium transporters in this species.

\section{$\mathrm{NH}_{4}{ }^{+}-\mathrm{Cl}^{-}$cotransport is central to} energy metabolism in bee retina A long series of papers have shown that, in drone retina, glucose is taken up exclusively by the glial cells, where it is converted to pyruvate then alanine. Tsacopoulos et al. (1994) proposed that the alanine is transferred to the photoreceptor neurons where it is deaminated to provide pyruvate for the numerous mitochondria (Fig. 2 C), and that ammonium is returned to the glia, to support sustained production of alanine from glucose or glycogen. Two experimental tools not available to the earlier workers have recently been used to test and refine this model (Coles et al. 2008). First, it was not known whether these neurons can actually use alanine as a fuel. Normally, in a retinal slice, the huge stocks of glycogen in the glia provide a supply of fuel to the neurons that lasts for many hours.

This supply can be reduced by $D A B^{2}$, an inhibitor of glycogen phosphorylase, as can be seen by a fall in $\mathrm{O}_{2}$ consumption by the mitochondria (present only in the neurons). It was found that application of alanine restored $\mathrm{O}_{2}$ consumption, as predicted (Fig. 2D). Second question: do the photoreceptors release ammonium? Instead of trying to guess ammonium movements from measurements of $\mathrm{pH}$, the authors used a triple-barrelled ammoniumsensitive microelectrode to directly measure $\left[\mathrm{NH}_{4}^{+}\right]$in the extracellular clefts. In normal Ringer solution, extracellular $\left[\mathrm{NH}_{4}{ }^{+}\right]$was below the detection limit of these electrodes. However, when $\mathrm{NH}_{4}{ }^{+}$uptake by the glia was blocked by removing $\mathrm{Cl}^{-}$ from the Ringer solution, 
extracellular $\left[\mathrm{NH}_{4}^{+}\right]$was measurable in the dark and shown to increase during light stimulation (Fig. 2E). Extracellular $\left[\mathrm{NH}_{4}^{+}\right]$was greatly reduced by methylaminoisobutyrate, a blocker of amino acid transport, and also by pyruvate, which was expected to provide a direct substrate for the mitochondria, bypassing alanine (Fig. 2F). Hence, in this preparation, we now have very strong evidence for the neurons being fuelled by alanine, with ammonium being returned to the glial cells and taken up by a specific transporter.

\section{A neuron-astrocyte ammonium- amino acid shuttle in mammalian brain?}

Mammalian astrocytes (at least in culture) avidly take up $\mathrm{NH}_{4}{ }^{+}$(see Marcaggi \& Coles, 2001). Most of the glutamate released at glutamatergic synapses in the mammalian brain is taken up into astrocytes by glutamate transporters where, in the astrocytes, it reacts with ammonium to form glutamine. Glutamine, which does not bind to synaptic receptors, is transferred back to the pre-synaptic terminals and deaminated to glutamate. By analogy with bee retina, the shuttle might be completed by transfer of ammonium from the neurons to the astrocytes, as originally proposed by Benjamin \& Quastel (1975). Fig. 3, is an update of this proposal which shows uptake of $\mathrm{NH}_{4}^{+}$rather than $\mathrm{NH}_{3}$, and the co-release of ammonium with neurotransmitters (Marcaggi, 2006).

Within the astrocyte, ammonium might act as a signal as well as a

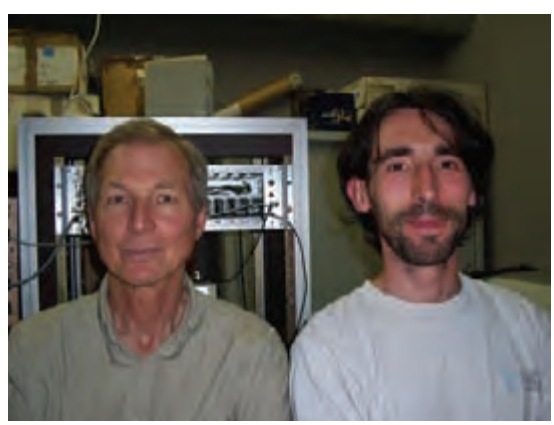

Jonathan Coles (left) and Païkan Marcaggi. reactant. For example, enzymes of the glycolytic pathway are stimulated by ammonium and exogenous ammonium does increase lactate production in rat brain in vivo (Provent et al. 2007). What would really help this field is a good membrane permeable ammoniumsensitive fluorescent indicator. Please tell your chemist friends.

\section{Païkan Marcaggi}

Department of Neuroscience, Physiology and Pharmacology, University College London

\section{Jonathan A Coles}

Grenoble Institute of Neuroscience, France (present address: Centre for Biophotonics, University of Strathclyde, UK)

\section{References}

Benjamin A \& Quastel J (1975). Metabolism of amino acids and ammonia in rat brain cortex slices in vitro: a possible role of ammonia in brain function. J Neurochem 25, 197-206.

Coles JA, Martiel JL \& Laskowska K (2008). A glia-neuron alanine/ammonium shuttle is central to energy metabolism in bee retina. J Physiol 586, 2077-2091.

Huang CH \& Peng ] (2005). Evolutionary conservation and diversification of Rh family genes and proteins. Proc Natl Acad Sci U S A 102, 15512-15517.

Javelle A, Lupo D, Ripoche P, Fulford T, Merrick M \& Winkler FK (2008). Substrate binding, deprotonation, and selectivity at the periplasmic entrance of the Escherichia coli ammonia channel AmtB. Proc Natl Acad Sci U S A 105, 5040-5045.

Marcaggi P (2006) An ammonium flux from neurons to glial cells. Proc Physiol Soc 3:SA16.

Marcaggi P \& Coles JA (2000). A Cl cotransporter selective for $\mathrm{NH}_{4}^{+}$over $\mathrm{K}^{+}$in glial cells of bee retina. J Gen Physiol 116, 125-141.

Marcaggi P \& Coles JA (2001). Ammonium in nervous tissue: transport across cell membranes and fluxes from neurons to glial cells. Prog Neurobiol 64, 157-183.

Provent P, Kickler N, Barbier EL, Bergerot A, Farion R, Goury S, Marcaggi P, Segebarth C \& Coles JA (2007). The ammonium-induced increase in rat brain lactate concentration is rapid and reversible and is compatible with trafficking and signaling roles for ammonium. J Cereb Blood Flow Metab 27, 1830-1840.

Tsacopoulos M, Veuthey AL, Saravelos G, Perrottet P \& Tsoupras G (1994). Glial cells transform glucose to alanine which fuels the neurons in the honeybee retina. J Neurosci 14, 1339-1351.

\section{Editor-in-Chief Elect}

The Physiological Society is seeking to appoint an Editor-in-Chief Elect for its prestigious publication The Journal of Physiology. The Editor-in-Chief Elect will work alongside the current Editorin-Chief from mid-2009 and then take over full editorial control in July 2010 when the present Editor-in-Chief, William Large, finishes his term of office.

Since 1878 The Journal of Physiology has published original research papers in all areas of physiology illustrating new physiological principles or mechanisms. It also publishes commissioned reviews and commentaries, and organises sponsored symposia, the proceedings of which are published as reports in The Journal.

The Editor-in-Chief works closely with the Managing Editor, Carol Huxley, and her staff at The Society's Publications Office based in Cambridge, UK. The Editor-in-Chief chairs regular meetings of The Journal's Executive Committee, comprising Senior Editors and representatives of The Society and the publishers (Wiley-Blackwell). This Committee is responsible for strategic planning and operational matters relating to The Journal. Serving under the Senior Editors is an international Editorial Board of over 50 members, which meets annually.

Candidates should submit a CV together with a letter of no more than three pages of A4 by 1 December 2008 summarising the following:

- a statement describing the reasons for their interest in the position;

- an assessment of the current state of The Journal;

- a vision for the future of The Journal and how it could be achieved;

- an opinion on the organisation and composition of the Editorial Board;

- any other comments that the candidate feels are relevant.

For full details go to

http://www.physoc.org

Going to the US next year?

If you are travelling to the USA after 12 January 2009 under the Visa Waiver Program you will need to apply for advance authorization using the online process available at https://esta.cbp.dhs.gov. 